\title{
The forage and grain yield of sorghum and maize as affected by soil moisture conservation, lodging and harvesting losses
}

\author{
H. van Arkel
}

UNDP/FAO Kenya Sorghum and Millets Development Project, P.O. Box 1275, Nakuru, Kenya

Accepted: 30 November 1977

Key words: forage crops, sorghum, maize, lodging, harvesting losses, soil moisture conservation, cold tolerance, drought resistance

\section{Summary}

The effects of early ploughing (before the start of the dry season) and late ploughing on the yields of a forage maize, and cold-tolerant forage and grain sorghum crops are reported. It appeared that on a shallow soil no significant effects on crop producton could be shown. But on a deep soil with good waterholding capacity, crop yields were increased considerably by reducing soil moisture evaporation in the dry period prior to the growing season.

The forage sorghum outyielded the maize, a difference which was accentuated when mechanized harvesting systems were used in lodged crops. The forage sorghum proved to be more lodging-resistant than maize but, even when lodged, was harvestable without too much difficulty. The use of small-plot maize yield trials is considered to have limited applicability to mechanized harvesting systems when presently available Kenyan maize hybrids are used. Lodging was the major limiting field factor for the harvesting of heavy maize crops.

The highest net yields recorded for maize and sorghum were 12.0 and 23.7 tons $\mathrm{DM} \mathrm{ha}^{-1}$, respectively. The higher yield of sorghum was probably not due to better drought resistance but to a lower lodging susceptibility and a longer growing period.

\section{Introduction}

In an earlier paper (van Arkel, 1977) the introduction of new sorghums, (Sorghum bicolor (L.) Moench), originating from the highlands of Ethiopia and Uganda, into the highlands of Kenya was discussed. It appeared that some sorghums equalled or outyielded maize (Zea mays L.) in terms of total dry matter (DM) production or grain yield. All yields reported were based on carefully hand-harvested small experimental plots and the observation was made that 
most maize plants had lodged severely. Hence the question was posed whether sorghums would have a greater advantage over maize if large-scale mechanical harvesting systems were used because of the expected harvesting losses in lodged maize crops.

Cultivation methods to conserve soil moisture are of prime importance in many dryland farming systems. A comprehensive discussion of these methods is given by Arnon (1972). In Kenya, however, little attention has been paid to this aspect of crop yield improvement as yet. No reports with regard to soil moisture conservation for forage crops are available. However, a study on wheat (Triticum spp.) (Poulsen, 1974) showed that under a 739-807 $\mathrm{mm}$ unimodally distributed annual rainfall and at $2135 \mathrm{~m}$ elevation, ploughing at the very beginning of the dry season conserved up to $125 \mathrm{~mm}$ of additional soil moisture, as compared with ploughing later in the same season. This early ploughing resulted in up to a $50 \%$ increase in subsequent grain yield.

The newly introduced, promising, cold-tolerant, high-altitude sorghums were grown in an area which is ecologically similar to the area which Poulsen had used. Hence the question arose whether sorghum yields could be increased by early ploughing to a similar extent.

The present paper describes two experiments designed to evaluate the effect of ploughing date on the yield of sorghum. At the same time the experiments were designed to study the difference between the yield obtained by careful handharvesting and mechanical harvesting, thus estimating the harvesting losses. In each of the two experiments two of the newly introduced cold-tolerant sorghums were compared with maize, which is currently the crop of choice in feedlot farming, to give a comparative baseline. Experimental observations on the incidence of lodging, and how lodging effects harvesting losses are discussed.

\section{Materials and methods}

\section{Trial sites}

Both experiments were conducted on the farm of the Kenya Government Beef Research Station near Nakuru. The study conducted formed part of the activities of the UNDP/FAO-sponsored Kenya Beef Industry Development Project.

Experiment 1 was laid down on a sandy loam with a shallow (approx. $30 \mathrm{~cm}$ ) topsoil overlaying a murram-pumice-lava mixture with a small water-holding capacity. In the previous year (1974) the trial area of the experiment had been used for nine strips $(35 \mathrm{~m} \times 400 \mathrm{~m})$ each of a different crop of either maize, sorghum or sunflower (Helianthus annuus L.). The trial site was located $40 \mathrm{~km}$ south of the equator at an elevation of $1860 \mathrm{~m}$. The average rainfall of the last 8 years was $786 \mathrm{~mm}$. The rainfall distribution for 1974 and 1975 is shown in Fig. 1.

Experiment 2 was laid down on a deep well-drained sandy loam, with excellent water-holding capacity. In the previous year (1974) the trial area of the experiment had been planted to a crop of forage maize. The trial site was located $35 \mathrm{~km}$ south of the equator at an elevation of $1920 \mathrm{~m}$. The average rainfall 


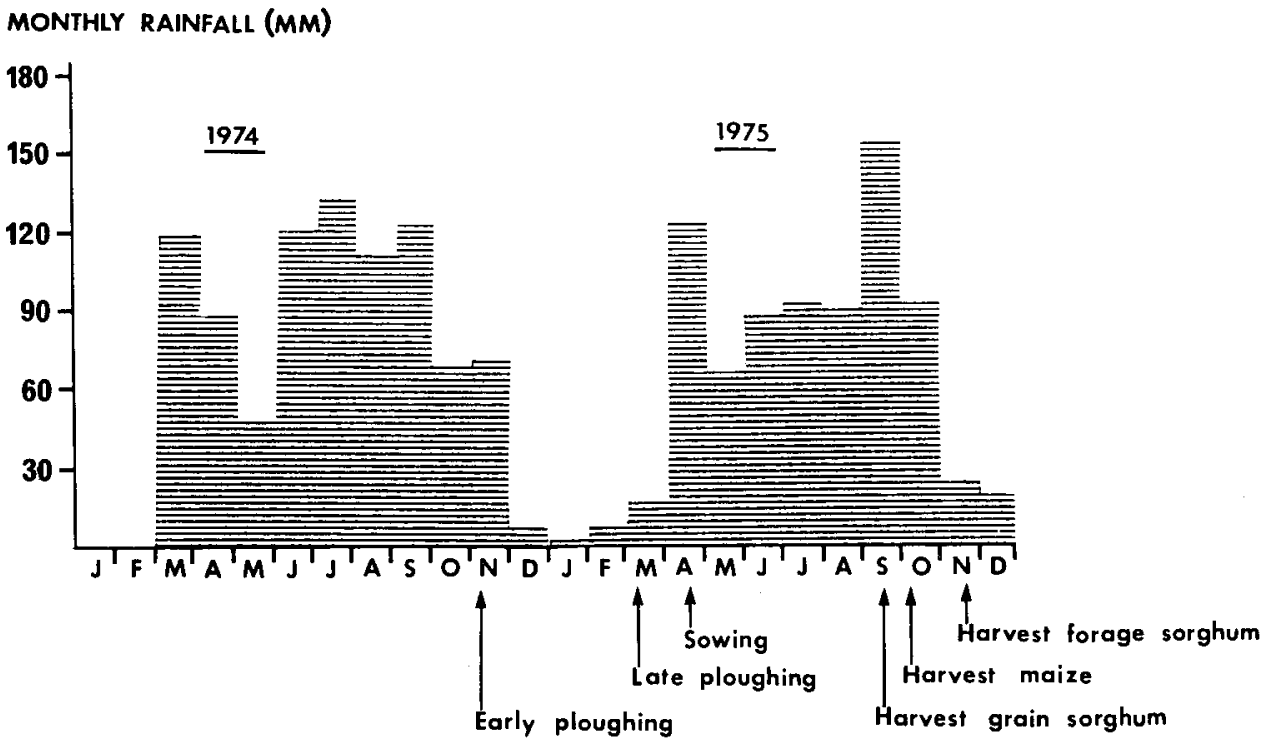

Fig. 1. Monthly rainfall during 1974 and 1975 and timing of operations in Experiment 1.

during the last 8 years was $960 \mathrm{~mm}$. The rainfall distribution for 1974 and 1975 is shown in Fig. 2.

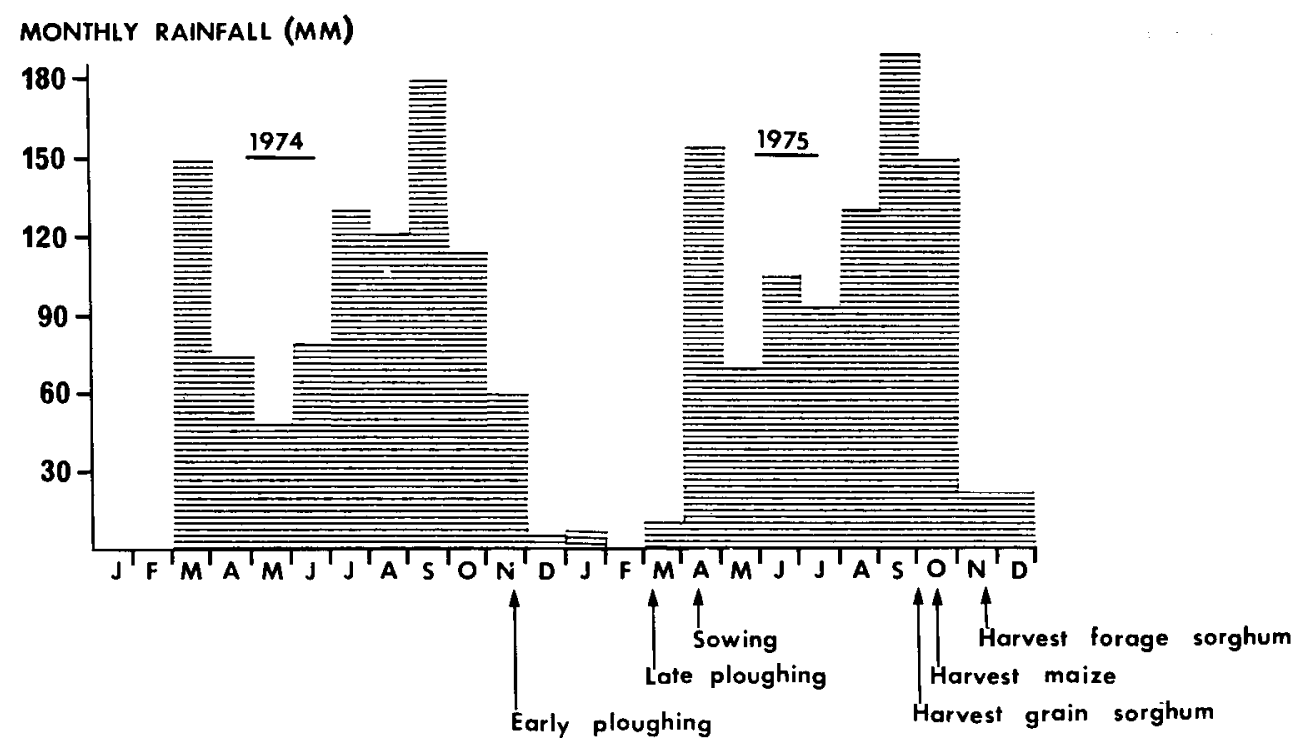

Fig. 2. Monthly rainfall during 1974 and 1975 and timing of operations in Experiment 2. 


\section{Crops}

The four crops studied were:

1) maize cv. 'H 613', a tall relatively late-maturing Kenya hybrid;

2) sorghum cv. 'E 1291', a relatively short, non-tillering cold-tolerant grain type;

3) sorghum cv. 'E 5766', a medium tall non-tillering, cold-tolerant type;

4) sorghum cv. 'E 6518', a tall multi-tillering, cold-tolerant forage type.

A more detailed description of the production characteristics and origin of the cultivars is given by van Arkel (1977).

\section{Ploughing date and experimental design}

In preparation for Experiment 1, the nine crop strips from 1974 were treated in the following manner. After harvesting the crops in 1974, each strip was divided into two halves; one was randomly selected to be ploughed immediately and kept bare until the planting season of 1975; the other received a soil moisture depletion treatment by not ploughing until just before the rains started in 1975 .

In April the field was sown to maize and grain sorghum ' $E$ 1291' and forage sorghum in three strips $350 \mathrm{~m}$ long by $130 \mathrm{~m}$ wide, so that the strips were at right angles to the 1974 strips.

In preparation for Experiment 2, the trial area which was sown to forage maize in 1974 was divided into 4 sections after harvest. Two of those sections, randomly selected, were ploughed immediately and kept bare by cultivating twice during the dry season. The other two sections were ploughed just before the rains of 1975. Each of the four sections was then sub-divided into three strips of $25 \mathrm{~m} \times$ $120 \mathrm{~m}$ to which maize and grain sorghum ' $\mathrm{E}$ 5766' and forage sorghum were allocated at random.

In both experiments the whole field was sprayed pre-emergence with atrazine at $2.5 \mathrm{~kg} \mathrm{ha}^{-1}$ active ingredient (a.i.) two days after sowing. The atrazine was very effective against most broadleaved weeds, but not very effective against grasses, mainly Cyperus esculentus (L.) and annual Setaria spp. In both experiments the plant density for the forage sorghum was 11 plants per $\mathrm{m}^{2}$. The plant density for the grain type sorghums in both experiments was around 18 plants per $\mathrm{m}^{2}$. The plant density of maize was purposely kept under the recommended density of 4.8 plants per $\mathrm{m}^{2}$ to reduce the risk of lodging. After plant establishment the average density was 3.6 plants per $\mathrm{m}^{2}$.

Both experiments were fertilized with $20 \mathrm{~kg} \mathrm{~N} \mathrm{ha}^{-1}$ and $60 \mathrm{~kg} \mathrm{P}_{2} \mathrm{O}_{5} \mathrm{ha}^{-1}$ in bands of compound fertilizer $15-45$ - 0 at the rate of $133 \mathrm{~kg} \mathrm{ha}^{-1}$ applied at sowing. All crops received a top dressing of $39 \mathrm{~kg} \mathrm{~N}^{-1}$ by broadcasting calcium ammonium nitrate at the rate of $150 \mathrm{~kg} \mathrm{ha}^{-1}$ when the crops had reached a height of $70 \mathrm{~cm}$.

In both experiments the crops were harvested with a forage harvester at the hard-dough stage of the grain. For the maize and forage sorghum, which had been sown in rows $85 \mathrm{~cm}$ apart, a row attachment was used on the harvester. The non-tillering grain type sorghums had been sown in $45 \mathrm{~cm}$ wide rows which were first cut with a reciprocating cutter bar, after which the crop was immediately picked up with the forage harvester fitted with a pick-up reel. The trailer 
loads were weighed on a weigh-bridge and samples were taken for DM analysis. The exact time of ploughing, sowing and harvesting in relation to the actual rainfall can be seen from Fig. 1 and 2.

One day before mechanical harvesting, from each plot were taken one (Exp. 1) or five (Exp. 2) handcut samples, each from $4.25 \mathrm{~m}^{2}$. These samples were taken to the laboratory for further plant component dissection and DM analysis.

It was assumed that the yields computed from the handcut samples gave the best estimate of the true yield because care was taken not to loose any plant material. From the comparison between this yield figure and the yield obtained by using the forage harvester, the harvesting losses were calculated.

\section{Lodging}

In Experiment 1 no lodging was observed, but the lodging in Experiment 2 was measured by two different techniques. For maize, where individual plants had fallen surrounded by unlodged plants, a few sample rows were taken and the number of lodged (angle of stem $<60^{\circ}$ ) plants were counted against the number of standing plants. For sorghum, which showed scattered patches in which all plants had lodged, an aerial grid estimation of the lodged proportion was made.

During the course of the experiments it was thought useful to obtain additional information on lodged versus unlodged forage sorghums. From each of eight different commercial sorghum fields, five lodged and five non-lodged adjacent patches, selected at random, were sample harvested $\left(4.25 \mathrm{~m}^{2}\right.$ each) and taken to the forage laboratory for component analysis.

\section{Results}

\section{Experiment 1}

Table 1 shows that ploughing date did not have a significant effect on either total DM yield or on grain yield. Thus the amount of soil moisture which was preserved in the soil by early ploughing was probably too little to ensure better growth in the following crop. The observation that the weeds left in the un-

Table 1. Effect of ploughing date on the total DM yield and grain yield of maize cv. ' $\mathrm{H}$ 613', grain sorghum cv. 'E 1291 ' and forage sorghum cv. ' $\mathrm{E} 6518$ ' in Experiment 1 (tons ha-1). (All yields obtained from hand-cut samples.)

\begin{tabular}{|c|c|c|c|c|c|c|c|c|}
\hline \multirow[t]{2}{*}{$\begin{array}{l}\text { Ploughing } \\
\text { time }\end{array}$} & \multicolumn{2}{|c|}{$\begin{array}{l}\text { Maize } \\
\text { 'H 613', }\end{array}$} & \multicolumn{2}{|c|}{$\begin{array}{l}\text { Grain sorghum } \\
\text { 'E 1291' }\end{array}$} & \multicolumn{2}{|c|}{$\begin{array}{l}\text { Forage sorghum } \\
\text { 'E } 6518 \text { ' }\end{array}$} & \multicolumn{2}{|c|}{ Average } \\
\hline & $\begin{array}{l}\text { total } \\
\text { DM }\end{array}$ & grain & $\begin{array}{l}\text { total } \\
\text { DM }\end{array}$ & grain & $\begin{array}{l}\text { total } \\
\text { DM }\end{array}$ & grain & $\begin{array}{l}\text { total } \\
\text { DM }\end{array}$ & grain \\
\hline early & 9.3 & 3.2 & 6.3 & 1.9 & 10.2 & 2.9 & 8.6 & 2.7 \\
\hline late & 9.2 & 3.3 & 6.1 & 1.8 & 10.4 & 2.6 & 8.6 & 2.6 \\
\hline
\end{tabular}

$\mathrm{SE}$ total $\mathrm{DM}$ yield $=1.32$ tons $\mathrm{ha}^{-1} ; \mathrm{SE}$ grain yield $=0.73$ tons $\mathrm{ha}^{-1}$.

Neth. J. agric. Sci. 26 (1978) 
Table 2. Harvested and grown DM. yields for the three crops studied in Experiment 1.

\begin{tabular}{|c|c|c|c|c|}
\hline & $\begin{array}{l}\text { Total field }{ }^{1} \\
\text { DM yield } \\
\text { (tons ha-1) }\end{array}$ & $\begin{array}{l}\text { Mean sample } \\
\text { DM yield } \\
\text { (tons ha-1) }\end{array}$ & $\begin{array}{l}\text { Harvesting } \\
\text { losses } \\
\text { (tons ha-1) }\end{array}$ & $\begin{array}{l}\text { Harvesting } \\
\text { losses } \\
(\%)\end{array}$ \\
\hline Maize 'H 613' & 10.0 & 9.3 & 0.7 & -7.5 \\
\hline Grain sorghum 'E 1291' & 5.9 & 6.2 & 0.3 & +4.8 \\
\hline Forage sorghum ' $\mathrm{E} 6518$ ' & 11.1 & 10.3 & -0.8 & -7.8 \\
\hline
\end{tabular}

SE of sample yields $=555 \mathrm{~kg} \mathrm{ha}^{-1}$.

1 Yields obtained by using a tractor-driven forage harvester.

2 Yields obtained by careful hand harvesting.

ploughed sections started wilting soon after the dry season of $1974 / 75$ had started supports this finding.

Table 2 shows that there were no significant differences between the sample yields and the actual yields. This indicates that at the relatively low yields of Experiment 1, harvesting losses did not occur.

\section{Experiment 2}

The amounts of DM grown after early and late ploughing were consistently higher after the former for each crop (Table 3a). The increase varied from $12.3 \%$ for maize to $24.6 \%$ for grain and $10.8 \%$ for forage sorghum. Maize and forage sorghum showed heavy lodging in the early ploughed plots, and this is probably the reason why the grain sorghum benefited relatively much more from early ploughing. The yield differences between the three crops studied are so large that they tend to overshadow the effects of ploughing date. Table $3 \mathrm{~b}$, however, shows clearly that the ploughing date effect on DM production is statistically significant $(\mathrm{P}<0.01)$.

In all three crops, harvesting losses were higher after early ploughing. Despite the increased harvesting losses in the heavier crops, early ploughing resulted in higher final yield for the two sorghums. By contrast, for the heavier maize crop the final net yield was not appreciably different from the lighter, late ploughed maize. This was because the extra harvesting losses due to lodging in the early ploughed treatment exceeded the increased DM production.

\section{Discussion}

\section{Ploughing date}

Early ploughing as a means of preserving soil moisture apparently only results in increased crop production on soils with a sufficiently high water-holding capacity. Visual observations in Experiments 1 and 2 showed that late ploughing allowed many weeds to produce viable seeds. In both experiments most of the resulting weeds were successfully killed by the herbicide. It must be assumed that if weed control would not have been so successful, the yield reduction from late ploughing would have been larger. 
On soils with a good water-holding capacity the beneficial effects of early ploughing are partly reduced by increased harvesting losses. Statistically there is no significant crop $\times$ ploughing date interaction for the harvesting losses. This means that the extra percentage of harvesting losses due to early ploughing is not necessarily different for the three crops studied. However, there is a tremendous interaction for the practising farmer because, for both sorghums, the extra harvesting losses due to early ploughing, are a small insignificant proportion of the total forage yield. For maize, by contrast, the extra amount of unharvested forage is a relatively important quantity and a significant proportion of the amount which is brought to the silage pits $(16.9 \%)$.

\section{Crop comparison}

In a previous paper (Arkel, 1977) the need for a forage crop more droughtresistant than maize has been argued. Cold-tolerant sorghum was presented as a possible source of promising material. Now the question again arises as to whether these sorghums indeed fulfil this need. The yield data presented in the present study fail to demonstrate the more drought-resistant nature of the sorghums. The productivity of the forage sorghum was $10.1 \%$ higher than the

Table 3a. The effect of ploughing date on the performance of maize and two sorghums in experiment 2.

\begin{tabular}{|c|c|c|c|c|c|c|}
\hline & \multicolumn{3}{|c|}{ Early ploughing } & \multicolumn{3}{|c|}{ Late ploughing } \\
\hline & $\begin{array}{l}\text { maize } \\
\text { 'H 613' }\end{array}$ & $\begin{array}{l}\text { grain } \\
\text { sorghum } \\
\text { 'E 5766' }\end{array}$ & $\begin{array}{l}\text { forage } \\
\text { sorghum } \\
\text { 'E 6518' }\end{array}$ & $\begin{array}{l}\text { maize } \\
\text { ' } \mathrm{H} 613 \text { ' }\end{array}$ & $\begin{array}{l}\text { grain } \\
\text { sorghum } \\
\text { 'E 5766' }\end{array}$ & $\begin{array}{l}\text { forage } \\
\text { sorghum } \\
\text { 'E 6518' }\end{array}$ \\
\hline DM production (tons ha-1) & 16.4 & 19.2 & 24.7 & 14.6 & 15.4 & 22.3 \\
\hline Net DM yield harvested (tons ha-1) & 11.8 & 18.2 & 23.7 & 12.0 & 14.8 & 22.1 \\
\hline Harvesting losses (tons ha ${ }^{-1}$ ) & 4.6 & 1.0 & 1.0 & 2.6 & 0.6 & 0.2 \\
\hline Harvesting losses (\%) & 28.3 & 5.3 & 4.1 & 17.8 & 3.9 & 0.9 \\
\hline Grain (\%) & 29.3 & 23.4 & 19.4 & 34.9 & 26.6 & 24.7 \\
\hline Grain yield (tons ha-1) & 4.8 & 4.5 & 4.8 & 5.1 & 4.1 & 5.5 \\
\hline Lodging (\%) & 33.2 & 2.0 & 76.7 & 18.7 & 0.0 & 8.3 \\
\hline
\end{tabular}

Table 3b. Analysis of variance on production data from Experiment 2, as shown in Table 3a.

\begin{tabular}{|c|c|c|c|c|c|c|}
\hline & \multicolumn{2}{|c|}{ Ploughing date } & \multicolumn{2}{|l|}{ Crops } & \multicolumn{2}{|c|}{$\begin{array}{l}\text { Ploughing date } \\
\times \text { crops interaction }\end{array}$} \\
\hline & $\mathrm{SS}(\%)^{1}$ & $\mathbf{P}$ & SS $(\%)^{1}$ & $\mathbf{P}$ & SS $(\%)^{1}$ & $\mathbf{P}$ \\
\hline DM production (tons $\mathrm{ha}^{-1}$ ) & 12.2 & $* *$ & 81.6 & $* * *$ & 1.8 & n.s. \\
\hline Net DM yield harvested (tons ha-1) & 2.8 & * & 92.8 & $* * *$ & 2.6 & n.s. \\
\hline Harvesting losses (tons ha-1) & 6.2 & $*$ & 84.5 & $* * *$ & 3.3 & n.s. \\
\hline Harvesting losses (\%) & 7.1 & $*$ & 82.8 & $* * *$ & 3.6 & n.s. \\
\hline Grain yield (tons $\mathrm{ha}^{-1}$ ) & 5.1 & n.s. & 51.2 & * & 19.4 & n.s. \\
\hline Lodging (\%) & 26.9 & $* * *$ & 44.1 & $* * *$ & 28.6 & n.s. \\
\hline
\end{tabular}

1 SS $\%=$ percentage of total sum of squares due to the level of significance.

${ }^{*} \mathrm{P}<0.05 ;{ }^{* *} \mathrm{P}<0.01 ;{ }^{* * *} \mathrm{P}<0.001 ;$ n.s. $=$ not significant. 
maize in Experiment 1, where total rainfall was $780 \mathrm{~mm}$; but under the wetter conditions of Experiment 2 (953 mm annual rainfall), the productivity of this sorghum was $50.6 \%$ higher than that of the maize. Two reasons for the higher productivity of sorghum can be suggested. Firstly, the forage sorghum had a growing season 42 days longer than maize, thus fitting the available rainy season much better (Fig. 1 and 2). Secondly, the sorghum was probably grown nearer to its optimal plant density than maize because the maize was deliberately planted at a sub-optimal density in order to reduce lodging. A furher important factor is the effect of lodging on net yields, giving maize a distinct disadvantage. Taken together, we must conclude that the side-advantages of sorghum (i.e. other than drought resistance) seem to be mainly responsible for its superior DM yield under mechanized farming systems in our area.

\section{Maize lodging}

Lodging in maize is a general problem in Kenya and the experiments reported in this paper give us an opportunity of studying some of the effects of it. The lodging percentage in the early ploughed sections of Experiment 2 was high (33.2 \%) but lodging to this extent is common (Squire, pers. comm.). Also van Arkel (1977) reported severe lodging in maize and Sheldrick (1974) stated: 'The increase of lodging is doubtless the major field factor limiting increase of yield from increased plant populations.' This was the reason why the plant population for maize (3.6 plants $\mathrm{m}^{-2}$ ) was kept lower than 4.8 plants $\mathrm{m}^{-2}$ needed for optimum DM production (Sheldrick, 1974; Allison, 1969).

The relationship between the grown yield, lodging and harvested yield is well exemplified in the data for early and late ploughing (Table 3a). A production increase from 14.6 to 16.4 tons $\mathrm{ha}^{-1}$ was negated by increased lodging and harvesting losses so that the heavier crop resulted in a yield approximately equal to that of the lighter crop (12.0 vs. 11.8 tons ha-1).

The presence of a heavy crop, whether resulting from early ploughing or from a productive soil, seems to be the prime cause of lodging. Since maize lodging was only absent in Experiment 1 where yields were relatively low, the conclusion emerges that there is a clear need for maize cultivars with a superior genetical standability. The lower plant population in our experiments was unable to prevent lodging. The effects of lodging are detrimental and although the harvesting loss percentage for early ploughed maize $(28.3 \%)$ may seem high, losses of this magnitude are common in maize crops in Kenya. Squire (unpublished data) has regularly observed and estimated losses of up to $50 \%$. It is because of this lodging susceptibility, and the losses involved, that small-scale trials in Kenya with careful hand-harvesting are considered to have limited applicability to mechanized harvesting systems.

In the next paragraph we will see that the effects of lodging in sorghum are less severe and therefore we will discuss the type of lodging most prevalent in maize. The lodging was uniformly scattered over the blocks of Experiment 2, and individual plants were uprooted and laid flat on the ground. This lodging followed three heavy rainstorms of a type common in Kenya. Such rain weakens 
the anchorage of the roots in the upper soil layers, as well as adding to the weight of the aerial part of the plant. The wind then exerts sufficient torque to induce lodging. The torque is increased by the tallness of the maize (stem lengths over $3.5 \mathrm{~m}$ are measured regularly). This type of lodging usually takes place when the plant's fresh weight is at its heaviest, at the middle of the grain formation. Most lodged maize plants lie flat on the ground and miss the harvester completely. Other individual lodged plants become entangled with unlodged plants due to the absence of pliability in the maize stem.

A small degree of a second type of lodging was seen, namely stem lodging occurring at the last stages of plant development, when some plants had started to dry out. The stalk becomes brittle at the top internodes, which dry out first. A heavy wind, with or without rain, will break some stalks, usually just under the node bearing a heavy cob. This lodging which may be exacerbated by stalk-borer damage, can be reduced by harvesting a little earlier than normal.

\section{Sorghum lodging}

The only sorghum crop which showed lodging to any appreciable extent was the forage sorghum in Experiment 2. Its lodging differed from maize lodging in that it resulted from stem bending. The lowest culm internode was at an angle of $30-45^{\circ}$ with the ground level, and at each higher internode the angle decreased until the top parts of the plants were horizontal. The different type of lodging in sorghum is probably associated with its stronger root system, in conjunction with its thinner and more elastic and pliable stem. The lodging also followed the torrential rainstorms mentioned above and was scattered in patches of at least $100 \mathrm{~m}^{2}$. But the type of lodging still allowed harvesting with a forage harvester without too much difficulty. The thinner, more pliable stems of the sorghums could be picked up by the harvester because the lowest culm part was still semiupright and above the harvester's cutting level.

In order to examine the cause and effect of sorghum lodging in more detail, production data from 40 lodged and 40 unlodged patches in 8 different but uniformly treated, commercial sorghum fields were collected. The results are tabulated in Table 4. From these data it appears that lodging was not associated with a higher plant or tiller density. This seems to lead to the conclusion that

Table 4. Production data for lodged and unlodged forage sorghum ' $E$ 6518' harvested at physiological maturity of the grains.

\begin{tabular}{llllll}
\hline & $\begin{array}{l}\text { Total DM } \\
\text { yield } \\
(\text { tons ha-1) }\end{array}$ & $\begin{array}{l}\text { Grain } \\
\text { yield } \\
(\text { tons ha-1) }\end{array}$ & $\begin{array}{l}\text { Plants } \\
\text { per ha } \\
(\times 1000)\end{array}$ & $\begin{array}{l}\text { Number of } \\
\text { tillers } \\
\text { per plant }\end{array}$ & $\begin{array}{l}\text { Grain } \\
(\%)\end{array}$ \\
$\begin{array}{l}\text { Non-lodged } \\
\text { Lodged }\end{array}$ & 20.6 & 4.82 & 53.6 & 2.62 & 23.4 \\
Significance & 17.7 & 2.66 & 58.0 & 2.50 & 15.0 \\
CV $(\%)$ & $*$ & $* * *$ & n.s. & n.s. & $* * *$ \\
\hline
\end{tabular}

${ }^{* * *} \mathrm{P}<0.001 ;$ n.s. $=$ not significant.

Neth. J. agric. Sci. 26 (1978) 
lodging is the result of a heavier crop, because lodging-causing diseases or pests were not present. The yield figures in Table 4, however, significantly suggest that the lodged sorghum had a lower yield at harvest. This must mean that during the period from lodging till harvest, i.e. the last $2 \frac{1}{2}$ months of growth, the unlodged crop had a faster growth rate than the lodged crop. Also, crop development in the lodged crops was significantly retarded, resulting in a lower grain percentage $(\mathrm{P}<0.001)$. This shows that lodging, also in sorghum, is disadvantageous and should be prevented where possible.

\section{Acknowledgments}

I am grateful to Dr M. J. Creek and Professor M. L. 't Hart for perusing an earlier draft and making helpful suggestions. My thanks are also due to the Kenya Government and to the UNDP and FAO for providing facilities and funds. This paper is published with the permission of the Director of Research of the Kenya Ministry of Agriculture, of the Director of the Plant Production and Protection Division of the FAO and of the Resident Representative of the UNDP.

\section{References}

Allison, J. C. S., 1969. Effect of plant population on the production and distribution of dry matter in maize. Ann. appl. Biol. 63: 135-144.

Arkel, H. van, 1977. New forage crop introductions for the semi-arid highland areas of Kenya as a means to increase beef production. Neth. J. agric. Sci. 25 (3): 135-150.

Arnon, I., 1972. Crop production in dry regions. Vol. 1 Background and Principles. Leonard Hill Book Co., London.

Jones, J. N., J. E. Moody \& J. H. Lillard, 1969. Effect of tillage, no tillage and mulch on soil water and plant growth. Agron. J. 61 (5): 719-721.

Poulson, K. K., 1974. Agronomic and cultural trials on wheat. FAO/DEN/TF 138. FAO, Rome.

Sheldrick, R. D., 1974. Evaluation of maize as a forage. Kitale 1968-1973. Tech. Rep. Natn agric. Res. Stn No. 2. Kitale, Kenya. 